\title{
Slope Stability Problems Along the Main Roads in the Kurdistan Region
}

\author{
Varoujan K. Sissakian ${ }^{1}$, Hassan O. Omer ${ }^{2}$ \\ ${ }^{1}$ College of Engineering, University of Kurdistan, Erbil, Kurdistan Region - Iraq \\ ${ }^{2}$ College of Engineering, University of Kurdistan, Erbil, Kurdistan Region - Iraq
}

\section{ABSTRACT}

The Kurdistan Region is covered by the relevant net of roads. Since the major parts of the Kurdistan Region are mountainous; therefore, the majority of them are in snake curve form. Construction of roads in mountainous areas will destroy the natural slopes, and when not treated; then different types of landslides will occur. Accordingly, the unstable slopes will cause a lot of risk to the traffic along the roads; endangering the driving along those roads; especially during winter season, and during and/ or shortly after heavy rain showers. The majority of the roads in the Kurdistan Region are planned, designed and constructed without considering the geological conditions, which include four parameters: 1) Type of the rocks and soils, 2) Dip direction and amount, 3) Intensity of joint planes, and 4) Weathering grade of the rocks. These are not considered due to: 1) Cost, 2) Construction's duration, 3) Choosing easier paths, 4) Absence of experience, 5) Absence of modern technology, 6) Absence of road construction codes, and 7) Ignorance of the factor of safety. We studied different examples from roads in the Kurdistan Region and presented different types of slope stability problems. Moreover, we presented recommendations to keep the stability along unstable slopes.

KEYWORDS : Road cut, Slope stability, Landslides.

\section{INTRODUCTION}

The roads in the Kurdistan Region suffer; mainly from slope stability problems; especially along road cuts in the mountainous areas. The slope stability problems increase; generally, with increasing the height of the slope and its gradient. However, the geological conditions along the roads play big role in the justification of the stability. We have noticed that the majority of the existing unstable slopes occurred due to haphazard road cuts, which means the landslides are of a man-made type. Many researchers have published a lot of books and papers concerning slope stability problems caused mainly due to different types of landslides. Among them; but not limited are; Varnes (1978), Varnes et al. (1984), Cruden and Varnes, 1996), Abramson et al. (2002), Wyllie and Mah (2005), Norris et

Academic Journal of Nawroz University

(AJNU) Volume 7, No 4 (2018).

Regular research paper: Published 21 December 2018

Corresponding author's e-mail : f.khajeek@ukhedu.krd

Copyright (C2017 Varoujan K. Sissakian¹, Hassan O. Omer².

This is an open access article distributed under the Creative

Commons Attribution License. al. (2008). Among all those studies, it is clear that the landslides can be divided into two main categories: 1) Natural, and 2) Man-made. Moreover, those of manmade are mainly caused due to haphazard road cuts. Wyllie and Mah (2005) published detailed explanations about rock slope engineering; including analyses of the slopes by different methods. Moghaddas and Ghafori (2007) reported about the distribution and causes of the landslides in Central Alborz, Iran. They discovered that the landslides are controlled by the weathering processes. Norris et al. (2008) published about the slope stability and erosion control, they presented different examples and how to control them.

\subsection{Location}

The study area includes the whole Kurdistan Region; however, each studied and presented case in this paper is shown in a detailed location map. Nevertheless, this doesn't mean that the cases shown in this paper are the only unstable slopes in the Kurdistan Region.

\subsection{Previous Studies}

Studies concerning the slope stability problems in the Kurdistan Region are very rare; as concerned with the size and extends of the existing landslides; however, some relevant studies, which dealt with the slope 
stability problems in the Kurdistan Region and elsewhere are mentioned bellow. Hamasour (1991) studied the unstable slopes (M.Sc. Thesis) and presented the main unstable parts of the Haibat Sultan crossing road. Sissakian and Ibrahim (2004 and 2005) reported about the geological hazards in Iraq and compiled the geological hazards map of Iraq at a scale of 1:1000000, they classified large parts of the Kurdistan Region within the unstable slope zone. Jassim et al. (2013) studied the unstable slopes of Haibat Sultan crossing road and considered the landslides and rock falls are the main mass movements' phenomenon present in the study area. They presented their work through 14 studied stations and concluded that the possibility of sliding is high. Sidiq et al. (2015) studied a landslide on Haibat Sultan crossing road that had happened on 11//11/ 2015 and documented the details and causes of the landslides; they also gave recommendations for stabilizing the concerned area. Jassim and Tokmachy (2015) studied the rock Mass Units of the abandoned Koya Tunnel and recorded different geotechnical properties of the unstable slopes. Noori and Hassan (2015) performed a slope stability assessment for some road cuts in Duhok Governorate. They concluded that "Majority of landslides and slopes' failures have occurred due to differential weathering and erosion or due geological and geomorphological factors or because of engineering work and the presence of joints and fractures, as well as because of the precipitation of heavy rain and snow in the winter season. Ibrahim (2017) reported about the unstable slopes along the Haibat Sultan crossing road. She conducted 18 studied stations and gave proposals to keep the road cuts stable. Sissakian and Omer (2018) studied a small landslide along the main Salahideen Shaqlawa road and explained the reasons of the landslide and gave recommendations to keep the stability of the road. Sissakian et al (2018 A) studied four large landslides along Dukan - Surdash main road and explained the reasons of the sliding and suggested many recommendations to keep the road cuts as stable as possible. Sissakian et al. (2018 B) studied the Haibat Sultan crossing road and presented the unstable slopes along the road through 11 stations. Moreover, they suggested many recommendations for stabilizing the unstable slopes.

\subsection{Materials and Methods}

In order to achieve the main aim of this study; we have used the following materials :

- Topographic and geological maps of different scales.

- Google Earth and FLASH Earth images.

- Different relevant geological published articles and reports. We have carried out field work in different places within the Kurdistan Region to recognize and study the details of the unstable slopes along some main roads, besides performing documentary field photos. Moreover, by using the available topographical and geological maps of different scales with the help of FLASH Earth and Google Earth images, we have indicated many unstable slopes suffering from different types of Landslides. In those parts, which we haven't performed field work, we measured the required parameters of the landslide from the satellite imagery and by using the topographic maps. In the field, we have mapped the limits of the landslides and significant parameters of the landslide were measured; such as crown area, shear plane, dimensions of the landslides, dip and strike measurements of bedding planes and joint planes are also measured. Moreover, we applied Landslides Possibility Index Method (Bejerman, 1994) in some of the landslides to indicate the possibility of reoccurrence.

\section{MAJOR CAUSES OF LANDSLIDES}

The causes of landslides can be divided into two main categories (Varnes, 1984, Varnes et al., 1984, Cruden and Varnes, 1996, Abramson et al., 2002, Norris et al., 2008, USGS, 2018) :

\subsection{Natural Causes}

The main causes are:

1.Extensive Rainfall, 2.Melting of snow, 3.Rivers, streams and valleys, 4.Change in groundwater level, 5.Seismic Shaking, 6.Geological conditions (Types of soils and rocks, weathering grade and jointing), and 7) Slope Conditions (Height and gradient)

\subsection{Man-made Causes}

The main causes are: 1.Constructions, 2.Slope changes, 3.Overweighting of slopes, 4.Agricultural activities, 5.Deforestation, 6.Mining operations, and, 7.Drawdown of reservoirs.

The aforementioned factors, in the both natural and man-made landslides can be briefed as the consequence of a complex field of forces, which are active on a mass of rock or soil on the slope (Westen, 2018). Basically, the two main determinative parameters are: 1.An increase of shear stress, and 2.A decrease of material strength.

\section{Increase in shear stress is related to}

1. Removal of lateral and underlying support (erosion, previous slides, road cuts and quarries).

2. Increase of load (weight of rain/snow, fills, vegetation).

3. Increase of lateral pressures (hydraulic pressures, roots, swelling of clay).

4. Transitory stresses (earthquakes, vibrations of trucks, machinery, blasting).

5. Regional tilting (geological movements

Reduction of material strength is related to

1. Decrease of material strength (weathering).

2. Change in state of consistency. 
3. Changes in intergranular forces (pore water pressure, solution).

4.Changes in structure (decrease strength in failure plane, fracturing due to unloading).

\section{GEOLOGICAL SETTING}

The majority of the exposed rocks in the Kurdistan Region are carbonates (Sissakian and Fouad, 2014); mainly limestone and dolostone, with different varieties covering $70 \%$ of the whole area, whereas igneous and metamorphic rocks cover only $4.9 \%$, as determined by GIS (Sissakian and Al-Khalidi, 2012). The degree of weathering of the rocks is a function of their hardness, disturbance and rainfall. As the disturbance of the rocks increases towards north and northeast of the Kurdistan Region; due to closeness' to the collision area of both Arabian and Iranian Plates (Fouad, 2012); therefore, the weathering degree increases. This is also affected by the rainfall intensity, which increases north and northeast ward. The authors have recognized that the majority of the roads run in soft rocks, which are mainly claystone (Fig. 1) and some sandstone. This is attributed to the fact that the soft rocks are easily excavated; accordingly, the construction of the road will be faster and the cost will be less. The consequences; however, are mainly causing failures of different types along the slopes. It is worth mentioning that the majority of those soft rocks are overlain by hard carbonate rocks, which may slide down when the underlying soft rocks are excavated as road cuts (Fig.1), which means hazardous zones. But, this doesn't mean that no roads are constructed in rocky terrain and all road cuts are stable. A good example is large landslides along Dukan - Surdash road, which runs in a rocky terrain and some of the slopes of the road cuts are unstable (Fig. 2).
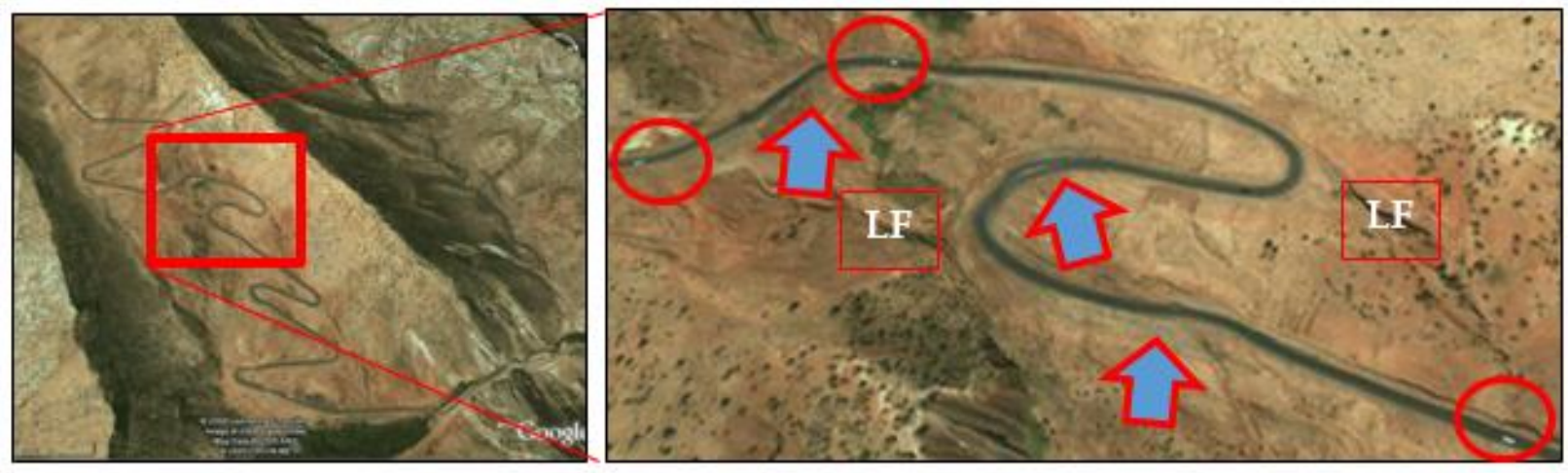

Fig (1) : Google Earth image showing a road cut in red claystone, between Zahko and Kani Masi. Note the damaged parts of the road (Arrows) and large fractures (LF). Cars are encircled in red for scale
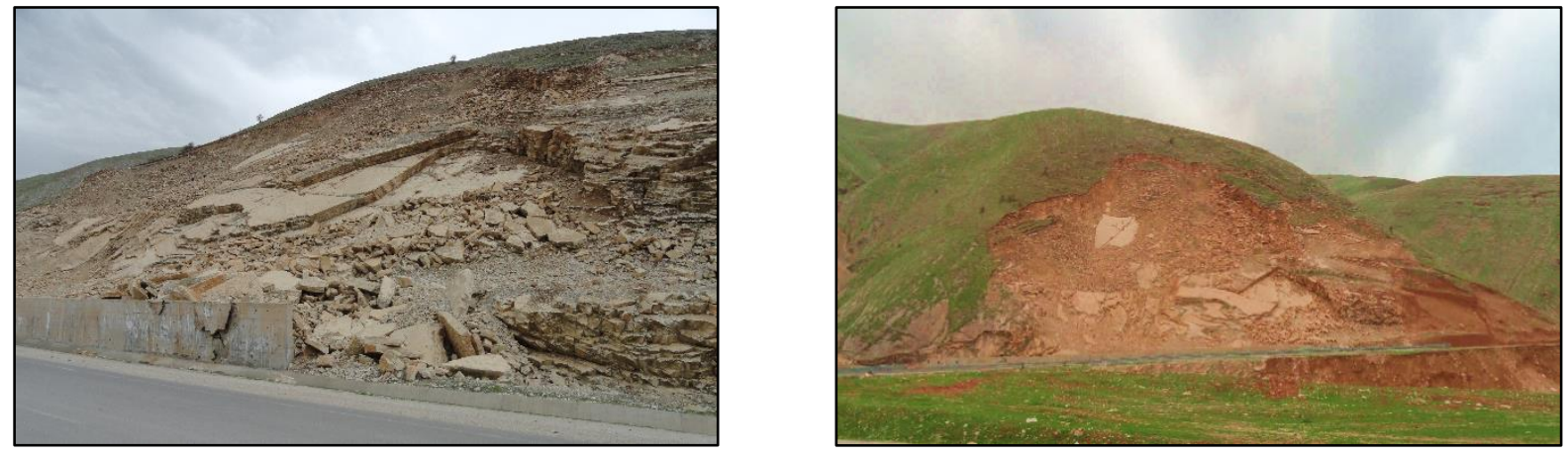

Fig (2) : Two landslides in rocky terrain along the main Dukan - Surdash road.

\section{RESULTS}

Besides the aforementioned reasons, which cause landslides and accordingly slope failures along the road cuts in the Kurdistan Region, the following reasons and/ or aspects were observed by the authors.

\subsection{Cost wise}

One of the most significant parameters in any construction project is the cost. For road constructions, excavations of road cuts and/ or blasting is one of the main objectives of the cost (Ghajar et al., 2013). The cost will increase with increasing the amounts of the excavated and/ or blasted materials. Therefore, the road cut slope is a function of cost; accordingly, the majority of the road cuts; unfortunately, are designed to be almost vertical or in very acute slope angle (Fig. 3). 

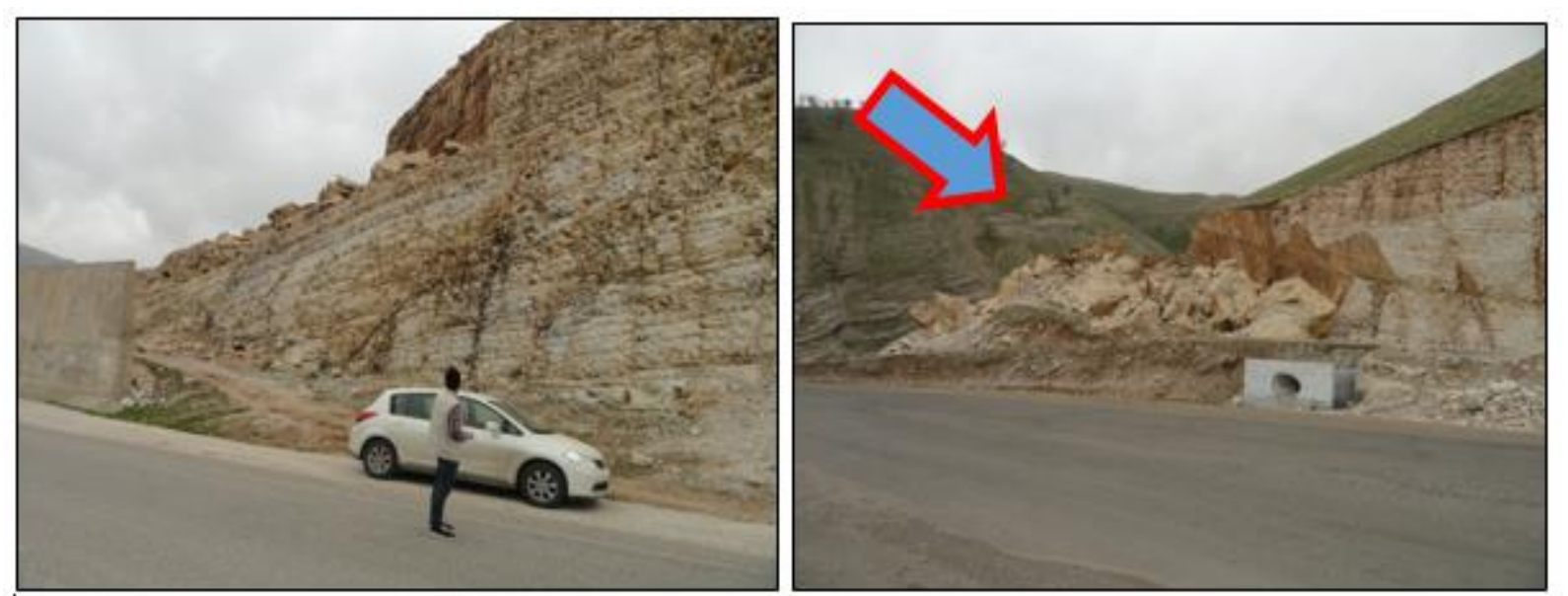

Fig (3) : Road cut along Dukan - Surdash main road. Left) Vertical road cut, but still is stable, Right) The same road cut and the same locality, but the slope failed due to the interference of the road cut direction and the attitudes of the bedding and jointing

The vertical slope; however, would be stable if studied relevantly to indicate: $\mathbf{1}$. The relevant road cut direction, 2.Direction and dip amount of the rocks (if the road cut is in rocks, 3.Mechanical properties of the soil (if the road cut is soil), and 4 .The height of the road cut. These parameters are again effecting positively on the cost, when relevantly studied.

\subsection{Duration of Construction}

Although duration is another function to the cost, but we have specified the duration as a separate factor. The required duration of road construction will increase with increasing of the road cut's slope degree; because more materials should be excavated and carried out (Burch, 2013). The more excavated materials will need more: 1.Machinery, 2. Labours, 3.Transportation of the excavated materials, 4.Dumping areas of the excavated materials, 5.Shaping of the excavated road cuts.

\subsection{Choosing Easier Paths}

Since majority of the Kurdistan Region is mountainous areas; therefore, the paths of roads cross many ridges and/ or mountains. Usually, the roads are designed to cross through gullies, valleys, and rarely they climb the

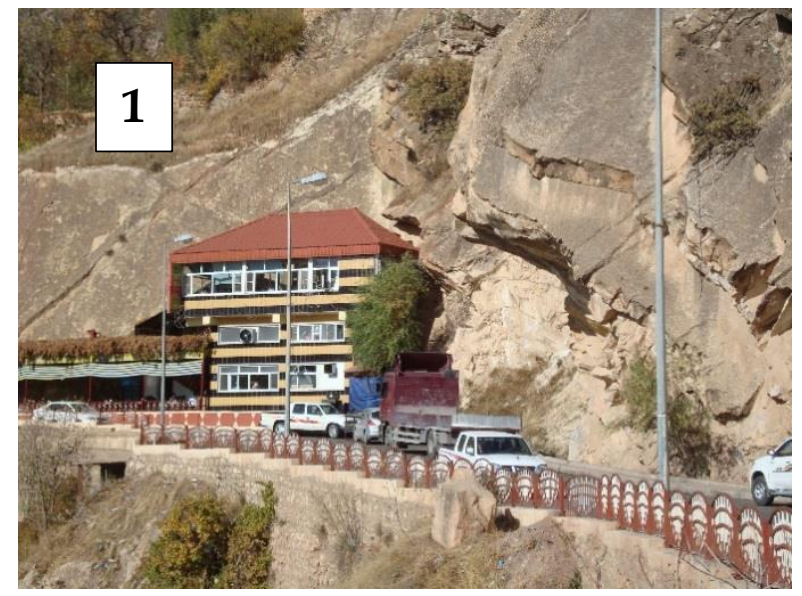

mountains or ridges. More recently; however, some tunnels are constructed through the paths.

In the Kurdistan Region, some of the road paths run through main gullies and/ or valleys. Certainly, they are easily constructed through those natural paths, which cross usually very high mountains; however, they are not safe enough. Good examples are Gulley Ali Beg, Gulley Zanta, Gulley Bekhme, Gulley Shamdinan, Gulley Amadia ...etc. (Fig. 4).

\subsection{Absence of Experience}

The designers of the majority of the roads in the Kurdistan Region do not have the required experience in designing of mountainous roads, especially the road cuts. Moreover, those who are working on implementing of the road cuts; they also lack the needed experience. All those road cuts are performed without any previous geotechnical study to indicate the relevant road cuts and the align the road paths through safe areas. Accordingly, the majority of the road cuts suffer from slope failure problems (Figs. 1, 2, 3 and 4).

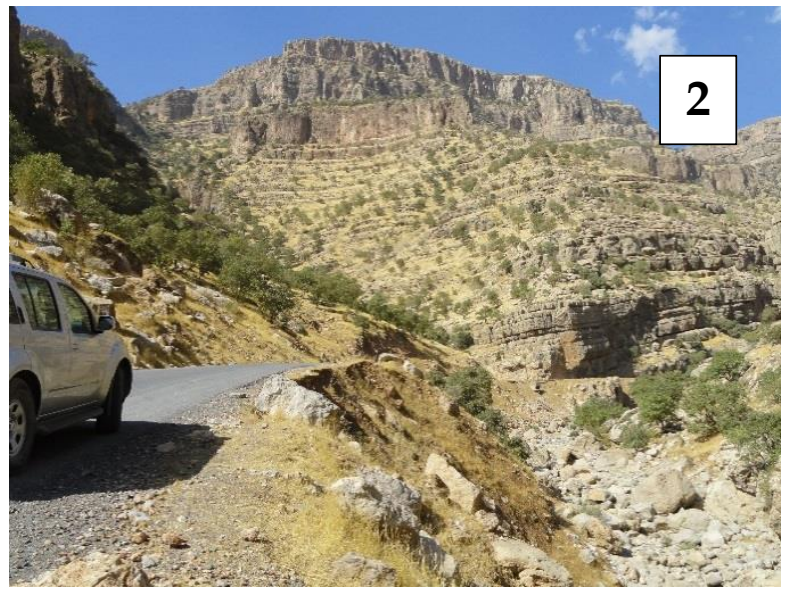



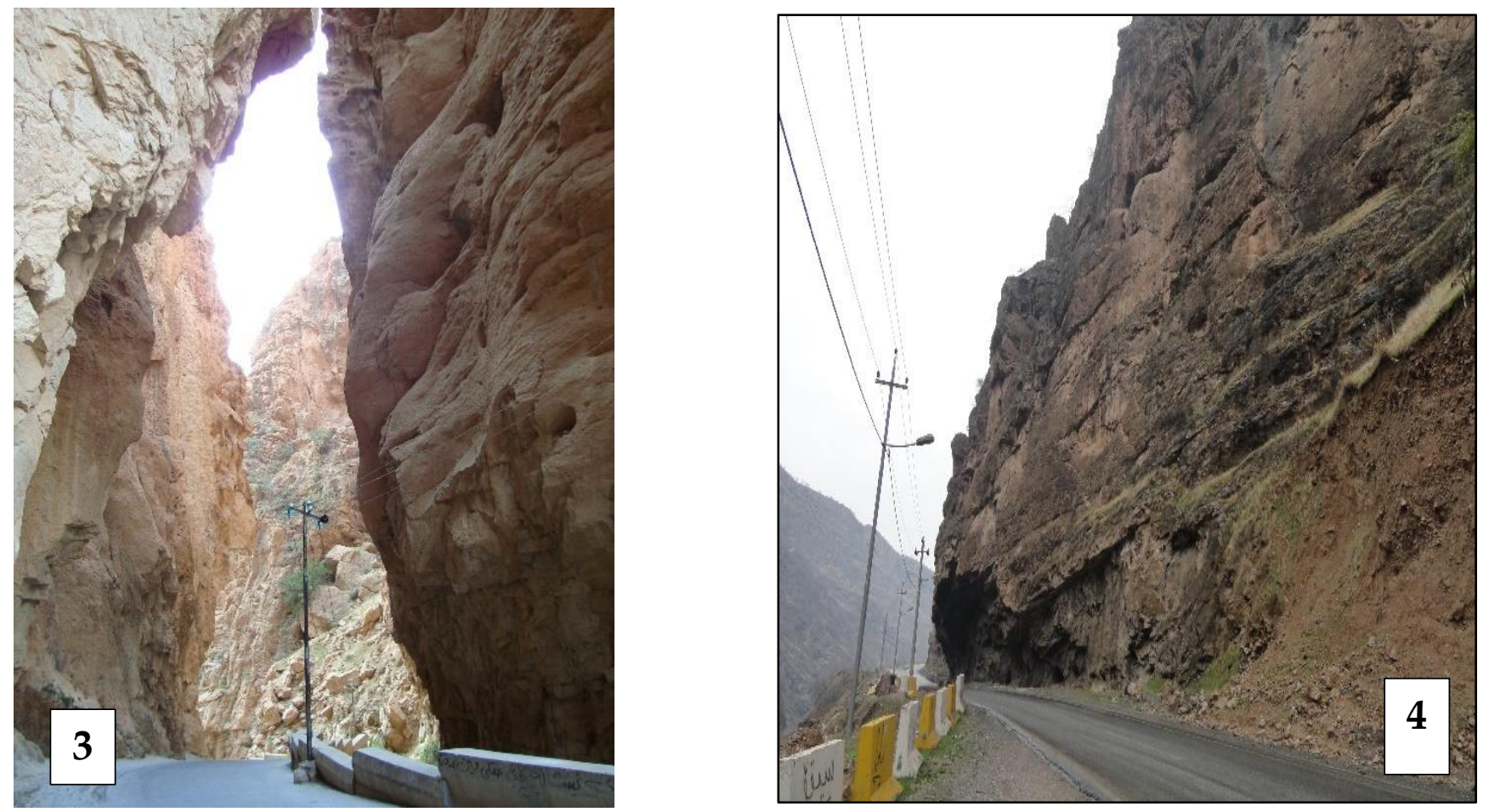

Fig (4) : Easy road paths, but not safe

1. Solav, 2. NW of Rawandouz,

3. Sartaq Bammu, and 4. Gulley Ali Beg

4.5. Absence of Modern Technology

The majority of the roads in the Kurdistan Region lacks the modern technology in treating the road cuts, such as using anchors, bolts, meshes, shot-crete, gabions, retaining walls...etc. However, very rarely such

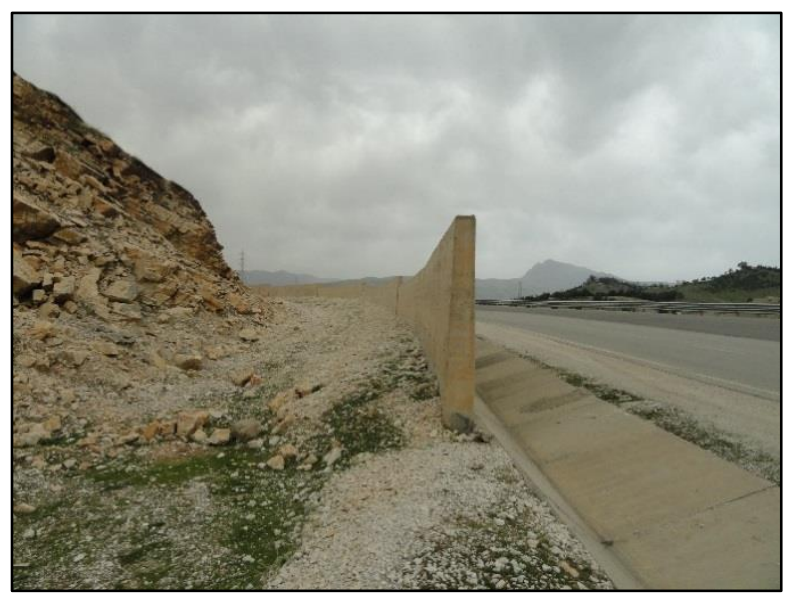

technology is used (Fig. 5, Top); even though some of the used aspects are not relevantly studied, designed and constructed (Fig. 5, Bottom). Accordingly, are damaged.

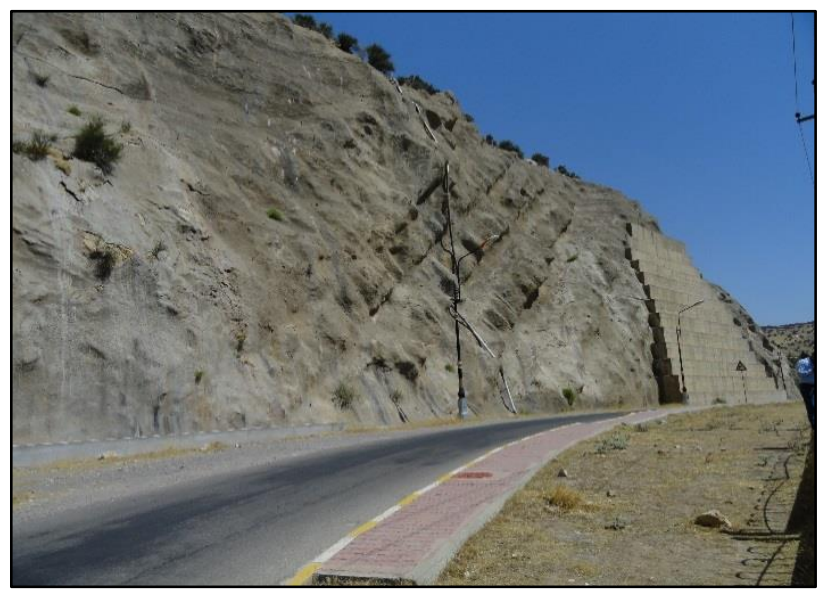



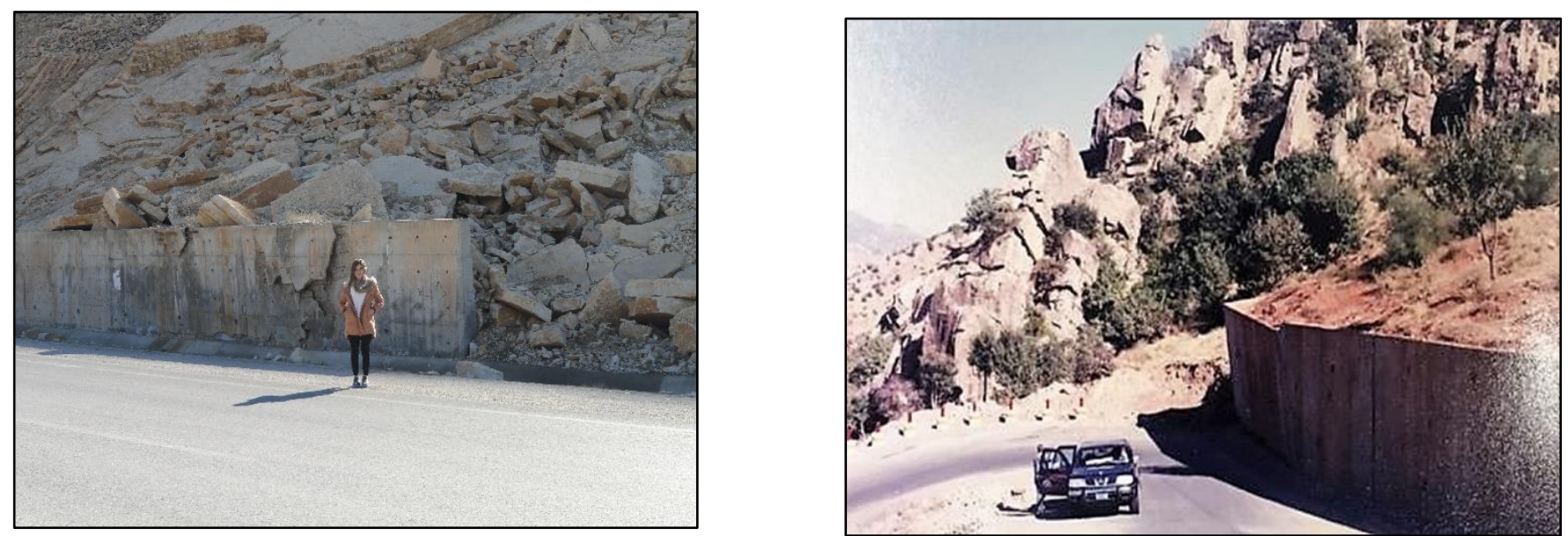

Fig (5) : Top, Left) Retaining wall facing unstable slope, Dukan - Surdash road, Top, Right) Retaining wall and shotcrete used in the treatment of unstable slope near Derbendikhan Dam. Bottom, Left) A damaged retaining wall,

Dukan - Surdash road, Bottom, Right) Inclined retaining wall, along the road crossing Mateen Mountain

\subsection{Absence of Road Design and Construction Standards}

The majority of the roads in the Kurdistan Region is constructed without following "Road Design and Construction Standards". Following regional or international code for designing road cuts will decrease the possibilities of landsliding and increase the factor of safety of the slopes along road cuts. A relevant code will supply the main aspects, which should be followed during road cut slopes' designs. A good example is the code given by Washington County (2011), it gives the following aspects:

a. Provide a safe and reliable multi-modal transportation system;

b.Preserve, protect, and improve the public transportation infrastructure;

c. Ensure the long-term viability of the transportation system; and

d. Avoid unnecessary and excessive maintenance and replacement costs.

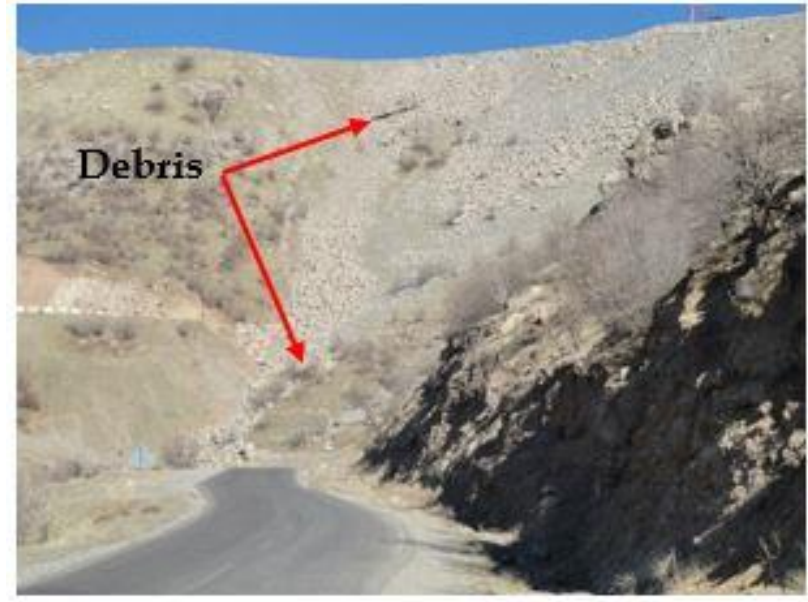

Fig (6) : Left) Road cut debris are dropped down slope without any treatment (Safeen road), Right) Overhanging cliff with slope full of debris (Gulley Ali Beg road)

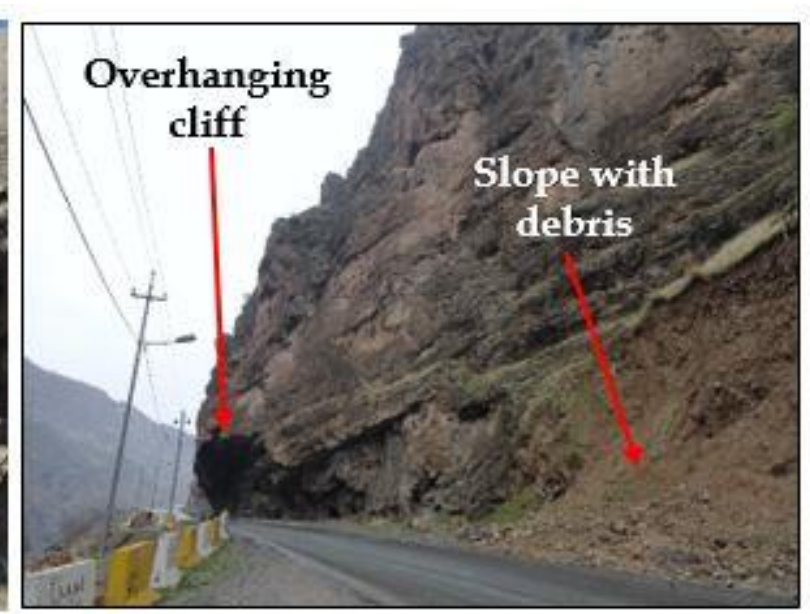

\subsection{Ignorance of the Factor of Safety}

The majority of the constructed roads in the Kurdistan Region lacks the factor of safety, as it is clear from the existing roads (Figs. 1, 2, 3, 4, 5 and 6). This is attributed to the lack of the necessary data at each road cut to indicate the factor of safety. However, to get the required data, a lot of work should be done, which needs money, time, expertise and equipment. The required data include: 1) Height of the road cut, 2) Slope angle of the road cut, 3) Density of the exposed rocks and/ or soil, 4) Friction angle of the exposed rocks, 5) Cohesion of the exposed rocks, 6) Orientation and inclination of the road cut, 7) Orientation and inclination (dip and strike) of the exposed rocks. Moreover, if tension cracks exist; then the depth and height of the water in the cracks should be measured too (Hoek and Bray, 1981, Zaruba and Mencl, 1982, Wyille and Mah, 2005). 


\section{DISCUSSION}

Slope failures within the road cuts along the main roads of the Kurdistan Region are very common. To decrease the possibility of landsliding, the road designers have to follow the instructions given in different international codes. Moreover, there are many methods which can be followed to indicate the possibility of landsliding; before the road cut or afterwards. Among those methods is the one created by Bejerman (1984), in which 10 parameters should be measured in each road cut to know whether the slope is safe or otherwise. This is very easy and applicable method to indicate the stability of slopes. To estimate the possibility of slope failure, the following parameters : 1.Slope height, 2.Slope angle, 3.Fracturing grade, 4.Weathering grade,
5.Gradient of discontinuities, 6.Spacing of discontinuities, 7.Orientation of discontinuities, 8.Vegetation cover, 9.Water infiltration, and 10.Existence of previous landslide (Bejerman, 1984). Each parameter has several choices and each choice has a grade, for example the height of the slope has five choices ( 1 to $8 \mathrm{~m}$; the grade is 1,9 to $15 \mathrm{~m}$; the grade is 2 , 16 to $25 \mathrm{~m}$; the grade is 3,26 to $35 \mathrm{~m}$; the grade is 4 , and $>35 \mathrm{~m}$; the grade is 5). After assigning the relevant grades to the 10 parameters, the total scored grade will be compared with six Landslide Possibility Index (Table 1) (Bejerman, 1984). Accordingly, the possibility of slope failure and Hazard Zone can be known.

Table (1) : Landslides hazard categories (After Bejerman, 1994)

\begin{tabular}{|c|c|c|c|c|}
\hline \multicolumn{3}{|c|}{ Landslide Possibility Index } & \multirow{2}{*}{\multicolumn{2}{|c|}{ Hazard Zone }} \\
\hline Grade & Category & Estimation & & \\
\hline VI & Very High & $>25$ & \multirow{2}{*}{$>25$} & \multirow{2}{*}{ High Hazard } \\
\hline $\mathrm{V}$ & High & $21-25$ & & \\
\hline IV & Moderate & $16-20$ & \multirow{2}{*}{$(11-25)$} & \multirow{2}{*}{$\begin{array}{l}\text { Moderate } \\
\text { Hazard }\end{array}$} \\
\hline III & Low & $11-15$ & & \\
\hline II & Very Low & $6-10$ & \multirow{2}{*}{$<10$} & \multirow{2}{*}{ Low Hazard } \\
\hline I & Small & $1-5$ & & \\
\hline
\end{tabular}

One of the main causes of slope failure is the water, since water plays a key role in producing slope failure. Water increases the driving force by loading, i.e., adding to the total mass that is subjected to the force of gravity, as well as seepage pressure. Chemical weathering (interaction of water with surface rock and soil) slowly weakens the slope material (primarily rock), reducing its shear strength, therefore reducing resisting forces. An increase in water also contributes to driving forces that result in slope failure. The weight (load) on the slope increases when water fills previously empty pore spaces and fractures. The shear strength of the slope material is decreased by increasing the pore water pressure (pressure that develops in pore spaces due to the increased amount of water) (Terzaghi, 1943 and Terzaghi et al., 1996).

Another significant factor that should be known during road cuts is the Safety Factor (SF), which is the ratio of resisting forces to driving forces:

\section{$\mathrm{SF}=$ Resisting Force $\div$ Driving Forces \\ If $\mathrm{SF}>1$ then the slope is safe \\ If $\mathrm{SF}<1$ then the slope is unsafe}

The Slope stability is therefore a function of: 1) Materials on the slope, 2) Strength of the materials, 3) Slope angle, 4) Climate, 5) Vegetation, and 6) Time.

Each of these factors may play a significant role in controlling driving or resisting forces (Watkins and Hughes, 2018).

The authors have observed that the majority of the road cuts within the Kurdistan Region lacks the modern technology to keep the stability of slopes by means of using scientific issues and modern technology. Even though, the used materials to keep the stability of the road cuts are not relevant (Figs. 2, Left, 5, Top; Left, Bottom, Left and Right, 6, 7 and 8). This is attributed to the mentioned reasons in section of the Results. 


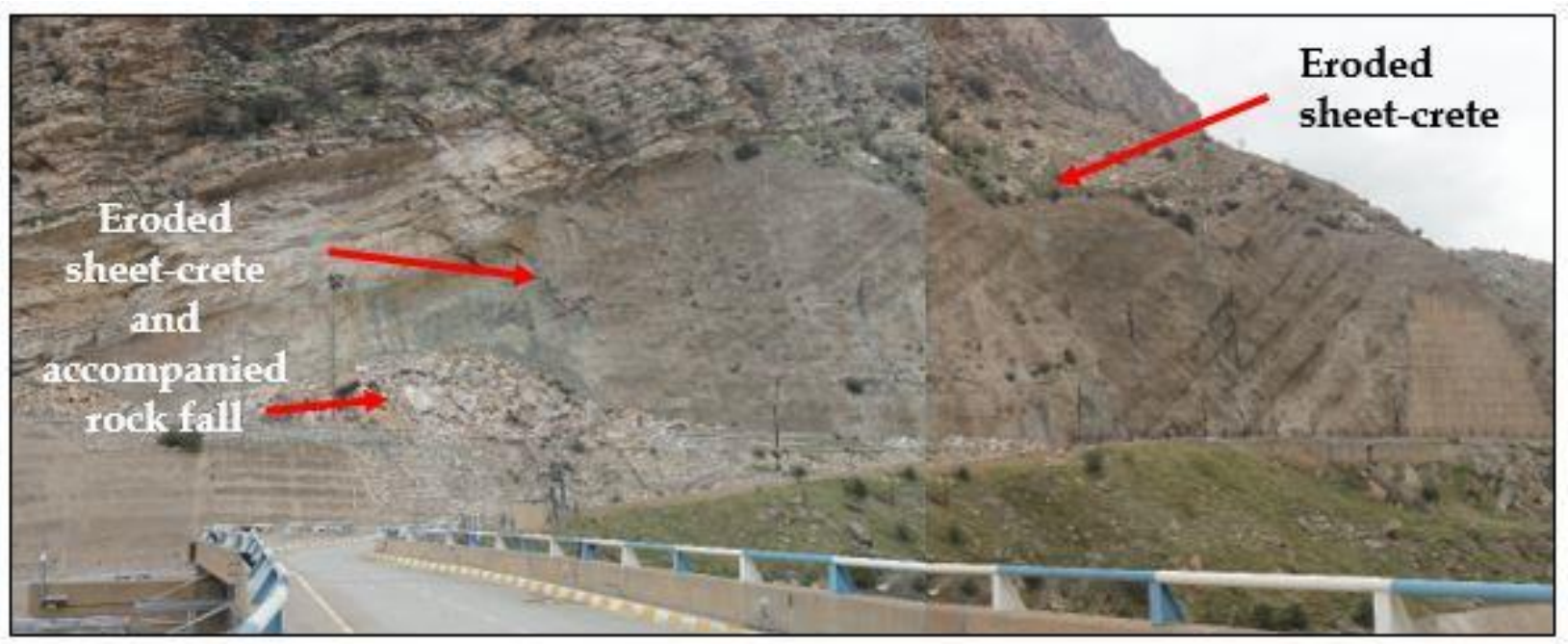

Fig (7) : A treated unstable road cut near Derbendikhan Dam. Note that the used sheet-crete is already damaged on the upper right side and the left side, it is accompanied by rock fall

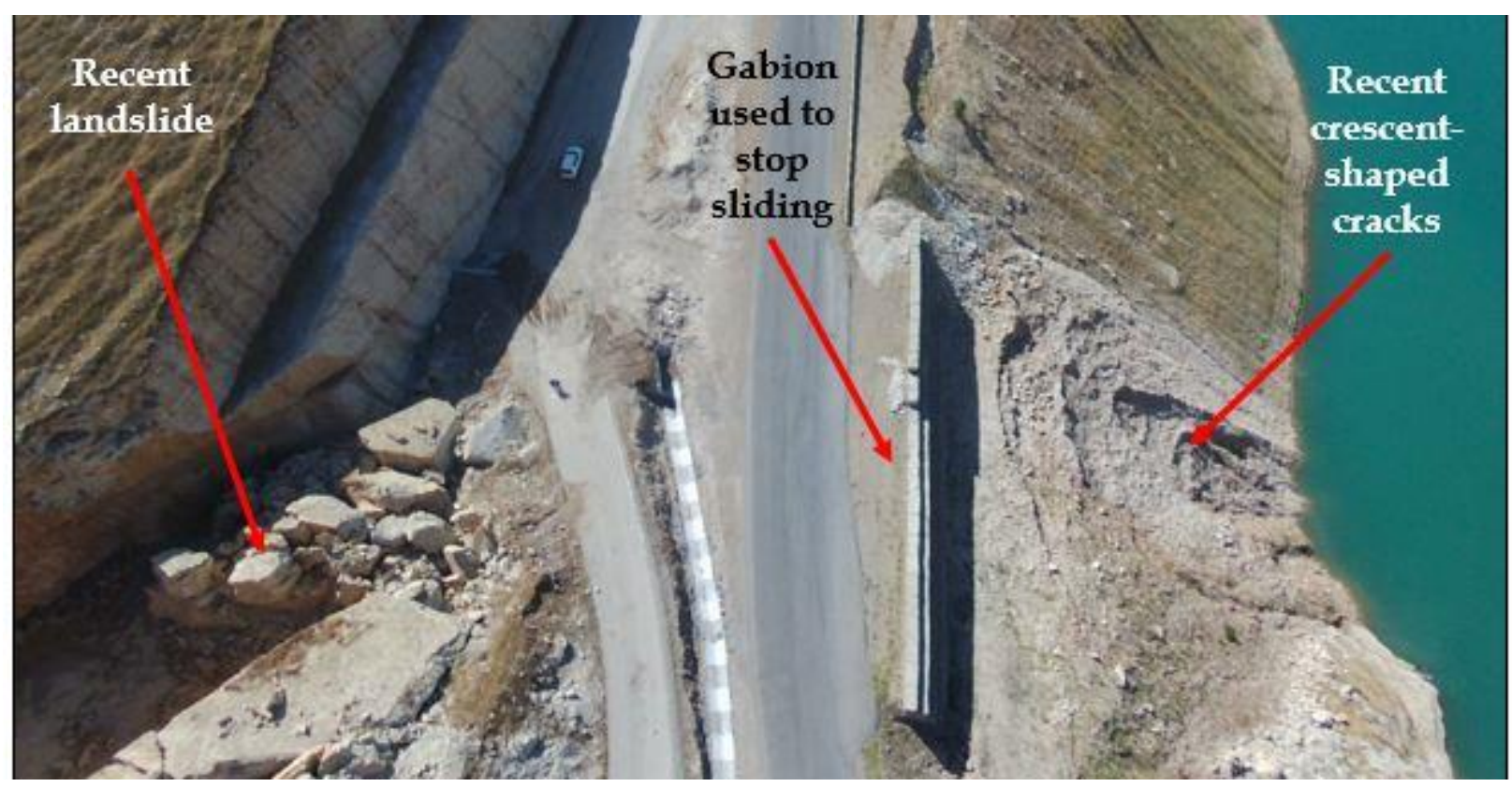

Fig (8) : Drawn photo showing bad treatment of a road cut that suffers from a landslide. Note the recent landslide, the used gabion and recently developed crescent-shaped cracks along the slope facing Derbendikhan lake

Another significant issue, which disturbs the road cuts and makes the slopes suffering from stability problems is the haphazard road cuts. Since the majority of the road cuts are performed haphazardly; accordingly, the slopes are not stable.

\section{CONCLUSIONS}

From observing different road cuts in different parts of the Kurdistan Region, we have the following conclusions: The majority of the road cuts are performed without taking in consideration the Factor of Safety. Almost all the roads are constructed without following international standards. Choosing the easiest paths by the road planners and designers had caused a lot of slope stability problems, especially along road cuts. No modern techniques are used; usually along the road cuts, even though they are not successively used and/ or installed.

\section{RECOMMENDATIONS}

To increase the Safety Factor along the road cuts, the following are recommended:

1.To use international standards during the planning and designing of the roads.

2. To insure that all road cuts have Safety Factor more than 1.

3. To use modern techniques in treating the unstable slopes.

4. To avoid haphazard road cuts 
5. To decrease the water infiltration into the slopes of the road cuts as less as possible.

\section{References}

1.Abramson, L., Lee, T.S., Shama, S. and Boyce, G.M. (2002). Slope stability and stabilization methods. John Whiley \& Sons Inc. 736 pp. www.wiley.com > .. > Soil > General Soil.

2. Bejerman, N.J. (1994). Landslide Possibility Index System. Proceedings 7th International Congress of IAEG, Balkema, Rotterdam, Vol. 3, p. 1303 - 1306. https://www.google.com/search?sclient=psy$a b \& c l i e n t=$ firefox-b\&q.

3. Burch, D., 2013. Estimating Excavation, 2nd edition. Craftsman Book Company. www.craftsmanbook.com/media/static/previews/...

4.Cruden, D.M. and Varnes, D.L. (1996). Landslide Types and Processes, Special Report, Transportation Research Board, National Academy of Sciences, 247:3675. www.researchgate.net/duplication/269710355...

5. Fouad, S.F. (2012). Tectonic Map of Iraq, scale 1:1000000, 3rd edition. Iraq Geological Survey Publications, Baghdad, Iraq. www.iasj.net $/$ iasj?func $=$ fulltext\&aId $=99665$.

6.Ghajar, I., Najafi, A., Karimimajd, A.M., Boston, K. andAli Torabi, S., 2013. A program for cost estimation of forest road construction using engineer's method. Forest Science and Technology, Vol. 9, Issue 3. https:// doi.org/10.1080/21580103.2012. 759163.

7.Hamasur, Gh.A., 1991. Engineering - Geological study of rock slope stability in Haibat Sultan area, NE Iraq. Un pub. M.Sc. thesis, University of Salahaddin, Erbil, Iraq. 153p. (in Arabic).

8.Hamed, H.M., Saad, S.A. and Ghafour, B.Dh., 2013. Slope stability assessment along the Haibat Sultan main road, Koya, Kurdistan. Proceedings of First International Symposium on Urban Development, Koya.

9.Hoek, E. and Bray, J. W., 1981. Rock Slope Engineering, 3rd edit. The Institute of Mining and Metallurgy, London, England, $358 \mathrm{pp}$. www.scirp.org/(S(oyulxb452alnt1aej1nfow45))/referen ce/...

10. Ibrahim, Z.J. 2017. Slope Stability at Haibat Sultan Road, Kurdistan Region, Iraq. Final Graduation Project, University of Kurdistan, Hewler, 46pp.

11. Jassim, H.M. and Tokmachy, A.A.M., 2015. Chracterization of Rock Mass Units Along the Abandoned Haibat Sultan Tunnel, Koya city, NE Iraq. International Journal of Engineering Technology, Management and Applied Sciences, Vol. 5, Issue 8, p. $158-176$.

12. Moghaddas, N.H. and Ghafori, M. (2007). Investigation of the Distribution of Causes of Landslides in Central Alborz, Iran. World Applied
Science Journal, 2 (6): 652 - 657.

13. Noori, H.J. and Hassan, M.M. (2015). Landslide Prone Sites Along Road Sections in Duhok with Suggested Remedies. Zanco Journal of Pure and Applied Sciences, Vol.27, No.6 (2015), pp. 121-136.

14. Sidiq, S.A., Muhmed, A.S., Haris, G. K., Hamma, D.M., Abdullah, M.M., Bibani, H.H., Muhealldin, H.K., Mustafa, H.A., Sissakian, V.K. and Al-Ansari, N., 2016. Mechanism of Haibat Sultan Mountain Landslide in Koya, North Iraq. Engineering, Vol.8, 535 - 544. Published online August 2016 in SciRes. http//:www. Scrip.org./journal/

http//:dx.doi.org/10.4236/eng.2016.880550.

15. Sissakian, V.K., \& Ibrahim, F.A. (2004). Report on Zonation of Geological Hazards in Iraq. Iraq Geological Survey Library Report No. 2878, 18 p. ltu.div portal.org/smash/get/diva2:1072054/FULLTEXT01.pd $\mathrm{f}$

16. Sissakian, V.K. and Ibrahim, F.A. (2005). Geological Hazards Maps of Iraq, Scale 1: 1000000. Iraq Geological Survey Publications, Baghdad, Iraq. www.oalib.com/references/7849110

17. Sissakian, V.K. and Saeed, Z.B., 2012. Lithological Map of Iraq, Compiled using GIS Techniques. Iraqi Bulletin of Geology and Mining, Vol. 8, No.3, p. 1 - 13. www.researchgate.net/profile/Varoujan_Sissakian/...

18. Sissakian, V.K. \& Fouad, S.F. (2012). Geological Map of Iraq, scale 1: 10000000, $4^{\text {th }}$ edition. Iraq Geological Survey Publications, Baghdad, Iraq. iasj.net $/$ iasj?func $=$ fulltext\&aId $=99666$

19. Sissakian, V.K. \& Al-Jiburi, B.S. (2014). Stratigraphy. In: The Geology of the High Folded Zone. Iraqi Bulleting of Geology and Mining, Special Issue No. 6, p. $73-161$. www.iasj.net $/$ iasj?func $=$ fulltext\&aId $=95647$

20. Sissakian, V.K. and Omer, H.O. (2018). Assessment of Unstable Slope in Korre Village, SW of Shaqlawa Town, the Kurdistan Region. Submitted to the Scientific Journal of University of Kurdistan, Hewler (UKHJSE). 21. Sissakian, V.K., Omer, A.S. and Mohamed, D.S. (2018). Assessment of Dukan Landslides, West of Sulaimani City, the Kurdistan Region, Northeast Iraq. Submitted to the Scientific Journal of University of Kurdistan, Hewler (UKHJSE).

22. Sissakian, V.K., Jassim, H.M., Vanarelli, M.J. and Omar, H.O., (2018). Stability Assessment of Haibat Sultan Crossing Road, North of Koya, the Iraqi Kurdistan Region. A Case Study. (In progress).

23. Terzaghi, K. (1934). Large Retaining Wall Tests. Engineering News Record Feb. 1, March 8, April 19.

24. Terzaghi, K. (1943). Theoretical Soil Mechanics. John Wiley and Sons. com/doi/10.1002/9780470172766.fmatter/pdf.

25. Terzaghi, K., Peck, R.B. \& Mesri, Gh. (1996). Soil Mechanics in Engineering Practice. John Wiley and 
Sons. https://www.abebooks.com/.../soil-mechanicsin-engineering-practice/.../terzaghi-karl-.

26. USGS (2018). What is a Landslide and what causes one? $\quad$ Retrieved from: https://www.usgs.gov/faqs/what-a-landslide-andwhat-causes-one?qt news_science_products=7\#qtnews_science_products.

27. Varnes, D.J. (1978). Slope movement Types and Process. In: Schuster, R.L. and R.J. Krizek, (Eds). Landslides: Analysis and Control (Washington, DC Transportation Research Board National Academy Press), Special Report, 176: 11-33. www.sciepub.com/reference/99674

28. Varnes and the International Association of Engineering Geology (1984). Landslide Hazard Zonation: a review of Principles and Practice. Published by the United Nattons Educalional. Scientific and Cultural Organization. www.worldcat.org/title/landslide-hazard-zonation-a... 29. Washington County (2011). Road Design and Construction Standards. Land use and Constructions. www.co.washington.or.us > .. > Consultant Resources 30. Watkins, A. and Hughes, S. (2018). Landslides, Slope Failure, and Other Mass Wasting Processes. Quoted from Keller, E. A. (2000). Environmental Geology, 9th edit. Chapter 6, p. 130 - 161. Upper Saddle River, N.J. : Prentice Hall, (2000. http://geology.isu.edu/wapi/EnvGeo/EG4_mass_was ting/EG_module_4.htm

31. Westen, C. (2018). Introduction to Landslides. Part 1: Types and Causes. Retrieved from: http://www.adpc.net/casita/Course\%20Modules/Lan dslide\%20hazard\%20assessment/Landslides_types_and causes.

32. Wyllie, D.C. and Mah, C. W. (2005). Rock Slope Engineering, Civil and Mining, 4th edition. Spon Press is an imprint of the Taylor \& Francis Group. Retrieved from

https:/ / civilenglineering.files.wordpress.com/2014/10 /rock_slope_engineering_civil_and_mining. 33. Zaruba, Q. and Mencl, V., 1982. Landslides and their Control. Elsevier Science. www.elsevier.com/books/landslides-and-their..

34. Zaruba, Q. (1969). Landslides and their Control. 1st edition, Czechoslovak Academy of Sciences, Elsevier, 24 pp.

play.google.com/store/books/details/Quido_Zaruba. 